\title{
Gruppebaseret eller individuel projekteksamen - fordele og ulemper
}

Anette Kolmos, professor og Jette Holgaard, lektor, Institut for Samfundsudvikling og Planlagning, Aalborg Universitet

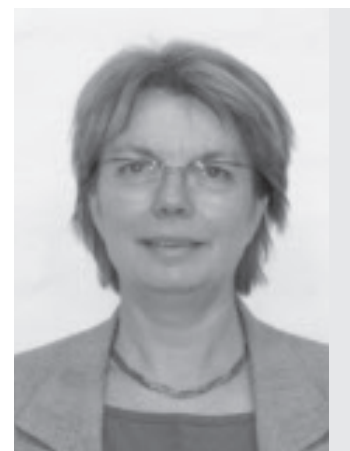

Anette Kolmos, ph.d., Professor og UNESCO Chair in Problem Based Learning in Engineering Education, Aalborg University, (www.ucpbl.net). Vicepræsident i SEFI (European Society for Engineering Education) og Chair af SEFI working group on Engineering Education Research. Har været leder af Pædagogisk Udviklingscenter, Aalborg Universitet 1995 - 2002 og har været en af de ledende kræfter i etableringen af Ingeniøruddannelsernes Pædagogiske Netværk. Har en ph.d. inden for køn og teknologi og har gennem hele sin karriere forsket inden for problembaseret læring specielt inden for tekniske og naturvidenskabelige uddannelser. Hun er associate editor for tidsskriftet: Journal of Engineering Education, ASEE, og European Journal of Engineering Education. Deltager i en række internationale advisory boards og er leder af Socrates projektet: PBLEngineering som står bag udviklingen af Master in Problem Based Learning - en international uddannelse der gennemføres som distanceundervisning (www.mpbl.aau.dk)

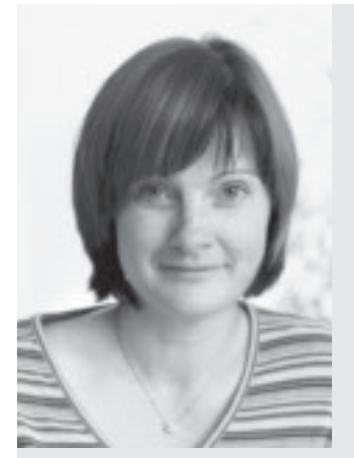

Jette Egelund Holgaard, M.Sc ph.d. Lektor inden for bæredygtighed, teknologi og organisatorisk læring. Er civilingeniør inden for miljøplanlægning og har skrevet ph.d. om miljøkommunikation $i$ et læringsperspektiv. Den nuværende forskning er fokuseret på samspillet imellem ingeniøruddannelserne, udviklingen i de teknologiske innovationssystemer og ingeniørernes rolle i en bæredygtig udvikling. Forskningen er tæt relateret til forskningsgruppen VIOL (Videnskabsteori, Ingeniørdidaktik og Organisatorisk Læring), Sektionen for Teknologi, Miljø og Samfund, Aalborg Universitet.

\section{Reviewet artikel}

I forbindelse med ministeriernes afskaffelse af gruppeeksamen (LBEK 280 of 21/03/2006), blev der etableret en storre komparativ undersøgelse på Aalborg Universitet (AAU) af den gruppebaserede eksamensform med individuel bedømmelse og den individuelle eksamensform. I denne artikel prosenteres resultater for sporgeskemaundersøgelse blandt studerende, vejledere og censorer, hvad angar styrkerne og svaghederne ved de to eksamensformer. Resultaterne viser, at den individuelle eksamensform ikke rummer den samme mulighed for at teste en rekke centrale projektkompetencer, og den respons, de studerende fär til deres projekt ved denne eksamensform, vurderes som mindre tilfredsstillende. Derfor er de didaktiske argumenter for den individuelle eksamensform svoere at finde. Hertil kommer, at majoriteten blandt de mere end 1000 studerende, eksaminatorer og censorer, der besvarede undersogelsen, ville foretrekke en gruppebaseret projekteksamen.

\section{Indledning}

Forundringen var stor, da der i regeringsgrundlaget for regeringen i 2005 stod: "Gruppeeksamen skal afskaffes«. Årsager til forundringen var for det første, at erhvervslivet igennem en årrække har rated Aalborg Universitet som den bedste uddannelsesinstitution i Danmark på en lang række områder inden for ingeniøruddannelse. For det andet har der aldrig kun eksisteret gruppeeksamen, men også en lang række individuelle eksamener. For det tredje har der gennem årene fundet en udvikling sted, hvor den individuelle bedømmelse reelt indgår som et led i den gruppebaserede eksamensform. For det fjerde er eksaminationen ikke alene blevet set som en mulighed for kontrol, men også en mulighed for læring. For det femte har den gruppebaserede projekteksamen været praktiseret på AAU ud fra den betragtning, at det var en naturlig forlængelse af et problembaseret projektarbejde i grupper - hvilket også den didaktiske forskning på området underbygger.

Afskaffelse af gruppeeksamen fandt formelt sted 
august 2007, men da de to involverede ministerier gennemførte forbuddet på forskellige tidspunkter, har det inden for diplomingeniøruddannelserne været gældende siden 2006. Dette gav en unik mulighed for at foretage komparative analyser af den gruppebaserede projekteksamen med individuel bedømmelse over for den individuelle projekteksamensform for at undersøge styrker og svagheder ved de respektive eksamensformer.

Der blev derfor, med start i foråret 2006, iværksat en undersøgelse af den gruppebaserede og individuelle eksamensform ved AAU samt ved udvalgte ingeniørhøjskoler i Danmark.

I denne artikel vil resultaterne af spørgeskemaundersøgelser i hhv. 2006, 2007 og 2008 på de tekniske, natur og sundhedsvidenskabelige uddannelser på AAU blive præsenteret med fokus på de tre forskningsspørgsmål, som præsenteres i det følgende.

\section{Baggrund for undersøgelsen}

Der er ikke megen national forskning at bygge på $\mathrm{i}$ sammenligningen imellem den gruppebaserede og individuelle eksamensform, hvad angår styrker og svaghederne $i$ at bedømme den enkeltes projektkompetencer (se dog Ingeniørcensorformandskaberne, 2008).

Internationalt er der forskning inden for "group assessment« (se fx Webb, 1993; Lejk et al., 1997). Dog er der ikke nogen komparative analyser af gruppeeksamen over for individuel eksamen, så der er ikke sammenlignelige resultater. Den internationale forskning er primært kendetegnet ved undersøgelser omhandlende selvevaluering og kollegial evaluering (peer-assessment) som elementer i den didaktiske proces til at øge studerendes læring. Inden for PBL-området bliver kollegial evaluering i par eller i større grupper anvendt, men der er langt overvejende tale om brug af disse former som formative evalueringsformer til understøttelse af læreprocessen. Forskningen inden for dette felt viser, at kollegial evaluering er med til at øge de studerendes læring (Dochy et al. 1999).

Inden for didaktisk forskning er det dog alment kendt, at der bør være overensstemmelse mellem uddannelsens mål, indhold og evalueringsformer. De didaktiske elementer har en indbyrdes afhængighed, hvilket betyder at hvis man ændrer i et af elementerne, vil det få betydning for de øvrige elementer (Biggs, 2003; Hiim \& Hippe, 1997). Det betyder, at ændrede eksamensformer vil have en konsekvens for de kompetencer, der tilegnes, og den læring, der finder sted. Et vigtigt element $i$ undersøgelsen har derfor været at undersøge relationen mellem udvalgte kompetencer og eksamensformer.

Det er altså ikke nogen hemmelighed iblandt didaktiske forskere, at eksamensformer styrer læreprocessen (Gibbs, 1999; Graaff, 2004). Igennem mange år har man i den engelske universitetsverden eksperimenteret med udvikling af eksamensformer til netop at øge de stude- rendes læring. En af de fundamentale problemstillinger, der har været arbejdet med, er at mange studerende har en overfladisk og instrumentel læring, hvor man udelukkende sigter på at lære det nødvendige for at bestå eksamen. Dette er den overfladiske læringsstrategi, hvor de studerende læser op til eksamen for at bestå, men med fare for, at de har glemt det hele igen kort tid efter. Fra en lærings- og kompetencesynsvinkel er denne form for læring ganske problematisk. Begrebet livslang læring handler bl.a. om, at den enkelte igennem et livsforløb er i stand til at udvikle sig gennem praksisorienteret læring på arbejdspladsen og formel læring i uddannelsessystemet. Dette betyder, at der skal være en indre motivation og drift for udvikling, som bl.a. opøves gennem en dybere læringsstrategi, hvor de studerende får lov at udforske, eksperimentere, designe og udvikle deres egne læringsforløb inden for nogle på forhånd afstukne faglige rammer. Men det betyder også, at eksamensformerne skal understøtte læreprocesserne.

I uddannelsen skal den individuelle viden selvfølgelig testes og bedømmes. Spørgsmålet er, hvordan man tester den individuelle viden, som er konstrueret igennem kollaborative processer $i$ et team? Teams består af individer og deres viden, så den enkeltes vidensmæssige bidrag er fundamentalt; men teamet består ikke kun af individers viden isoleret set, men af individers viden $i$ et holistisk samspil. Forestillingen om, at vidensudvikling finder sted individuelt, er forældet. En af de førende amerikanske forskere inden for kollaborativ læring finder, at kollektive processer ligger til grund for innovation (Sawyer, 2006; 2007). Samspil er derfor afgørende for teamarbejde, idet et team kan betragtes som en gruppe, der arbejder sammen mod et fælles mål. Hvis den enkelte ikke kan formidle sin viden eller ikke er i stand til at forstå andres viden og bygge videre herpå, så vil et team ikke være i stand til at løse komplekse opgaver, ligegyldigt hvor brillante de enkelte individer er.

Det er kendetegnende for det teknisk-naturvidenskabelige område, at udvikling af højteknologi kræver et fokus på teamet i stedet for det individuelle bidrag, da innovationsprocessen i høj grad er distribueret. For den arbejdende ingeniør er det ikke individets præstation, men teamets samlede præstation, som er indlejret i det produkt, som er resultatet af innovationsprocessen. Individets bidrag til teamarbejde er afgørende, men højteknologiske opgaver er så komplekse, at de ikke på nogen måde kan løses af enkeltpersoner. Den teknologiske viden er i dag overvejende systembaseret, og de færreste virksomheder kan opretholde ekspertise inden for alle hjørner af en given teknologi, hvorfor der også er stor behov for tværkulturelle samarbejdskompetencer. Der er behov for, at vidensdannelsen foregår i et kollektivt samspil på tværs af faglige, organisatoriske og nationale grænser. Dvs. at den enkeltes viden skal ses i relation til andres viden, og kompetencerne til at indpasse og udvikle sin viden $i$ et samspil med omgi- 
velserne bliver central, hvorfor dette må være et af de centrale mål for de ingeniør- og naturvidenskabelige uddannelser.

Problembaseret projektarbejde er udtryk for en integreret læringsstrategi, hvor man på en gang kobler det faglige indhold med læringsmetoden (Graaff \& Kolmos, 2007). Læringsmetoden er i sig selv kompetencegivende, hvad angår kompetencer som samarbejde og kommunikation. Hvor mange andre universiteter har adskilt læring af proceskompetencer og faglige kompetencer og igennem de sidste 10 år har etableret centre for læring af proceskompetencer, så har det altid været en integreret del af PBL-systemerne. I Tyskland er der eksempelvis gennem de seneste 10 år blevet etableret en lang række centre for "nøglekvalifikationer " for netop at opfylde krav om kommunikation og samarbejde. Det er derfor vigtigt at undersøge, hvordan respondentgrupperne vurderer de to eksamensformer $\mathrm{i}$ forhold til en række kompetencer inden for problemorienteret projektarbejde.

Hvis der skal være overensstemmelse imellem mål, indhold og eksamensform, kunne det derfor forventes at de studerende, ud over den fagspecifikke forståelse og de analytiske og metodiske kompetencer, også får testet deres evne til projektledelse, kommunikation og samarbejde, som netop kendetegner et problembaseret projekt $\mathrm{i}$ en gruppe til forskel fra et individuelt arbejde. Dertil kommer at det skal testes, om de studerende evner at overføre elementer fra det eksemplariske projekt til anden problemløsning. Det helt centrale spørgsmål i sammenligningen imellem gruppeeksamen og individuel eksamen er derfor:

I hvilket omfang rummer den individuelle eksamen og den gruppebaserede eksamen mulighed for at teste de studerendes faglige forståelse og kompetencer?

Et andet væsentligt forhold er muligheden for at lade kontrol og læring sameksistere i en eksamenssituation, hvor de studerende har fået direkte spørgsmål til deres projekt, men som også har testet de studerendes evne til at reflektere og perspektivere deres arbejde. Dette foranlediger følgende forskningsspørgsmål:

I hvilket omfang rummer den individuelle eksamen og den gruppebaserede eksamen mulighed for at stille både kontrolog perspektivsporgsmål til projektet.

Det er disse to spørgsmål, som danner grundlag for diskussionen af styrker og svagheder ved den gruppebaserede kontra den individuelle projekteksamen i denne artikel, velvidende at der er flere forhold, der gør sig gældende i den studerendes, censorernes og eksaminatorernes stillingtagen til projekteksamensform. I Kolmos et al. (2007b; 2008) er der fokus på en lang række andre områder herunder differentiering og eksamensformens betydning for arbejdsprocessen, og det har ikke været muligt at behandle alle disse forhold i en og samme artikel.

For at kunne sætte de didaktiske overvejelser i relation til aktørernes helhedsvurdering af projekteksamensform, fokuseres der i stedet på aktørernes overordnede præferencer for eksamensform med udgangspunkt i følgende spørgsmål:

Hvad foretrekker de studerende, censorerne og eksaminatorerne som projekteksamensform, når alt tages $i$ betragtning.

Før gennemgangen af resultaterne $i$ henhold til de ovenstående forskningsspørgsmål vil vi kort gennemgå den nødvendige baggrundsinformation, hhv. en introduktion til den gruppebaserede og individuelle eksamensform, som de traditionelt er blevet praktiseret ved AAU, og derefter give en kort gennemgang af den anvendte metode og baggrundsfaktorerne for undersøgelsen.

\section{Eksamensformerne}

Den gruppebaserede eksamen med individuel bedømmelse har været traditionel på Aalborg Universitet, og den typiske procedure er uddybet i tabel 1 . Tidsangivelsen gælder for en gruppe på 6 personer ved De Ingeniør-, Natur- og Sundhedvidenskabelige Fakulteter (INS fakulteterne).

Tilsvarende fremgår forløbet af den individuelle eksamen af tabel 2. Tidsangivelsen ved den individuelle eksamen er afhængig af semester, uddannelse og ikke mindst hvilket årstal. Generelt er der nemlig en tendens til at de individuelle eksamener bliver længere og længere.

\section{Metode og baggrundsfaktorer}

Med ovenstående overvejelser blev der udarbejdet et samlet design for undersøgelsen, hvor der blev anvendt både kvalitative og kvantitative metoder. Den kvalitative del af undersøgelsen omhandler interview og videooptagelser og er langt fra afsluttet på nuværende tidspunkt. Der er også foretaget andre dataindsamlinger i forbindelse med undersøgelsen, bl.a. omkring karaktergivning, men indsamlingen og analysen af disse data har dog været forbundet med en række vanskeligheder, bl.a. som følge af konverteringsproblemer mellem 13-karakterskalaen og 7-trins skalaen. Derimod er den kvantitative del med anvendelse af spørgeskemaer afrapporteret i seks delrapporter (jf. Kolmos \& Holgaard, 2007a; 2007b; Holgaard et al., 2008a; 2008b; Kolmos et al., 2008; Clemmesen et al., 2008).

Næsten enslydende spørgeskemaer har været udsendt til studerende, eksterne censorer og vejledere/ eksaminatorer ved alle tre fakulteter ved AAU og ved 


\begin{tabular}{|c|c|c|c|}
\hline $\begin{array}{l}\text { Faser i } \\
\text { eksamensforløbet }\end{array}$ & De studerende & Eksaminator og ekstern censor & Individuel bedømmelse \\
\hline \multirow[t]{3}{*}{$\begin{array}{l}\text { Mundtlig præsentation } \\
\text { af projektet: I time }\end{array}$} & & Byder velkommen & \\
\hline & $\begin{array}{l}\text { Mundtlig præsentation af } \\
\text { projektet, max. } 10 \text { min. pr } \\
\text { studerende. }\end{array}$ & & $\begin{array}{l}\text { Første indtryk af } \\
\text { de studerende med } \\
\text { individuelle markeringer }\end{array}$ \\
\hline & $\begin{array}{l}\text { De studerende svarer ved at } \\
\text { markere. }\end{array}$ & $\begin{array}{l}\text { Tager en runde med forståelsesspørgsmål } \\
\text { og kommentarer til de mundtlige } \\
\text { præsentationer både hvad angår form og } \\
\text { indhold. }\end{array}$ & $\begin{array}{l}\text { Løbende vurdering af de } \\
\text { enkelte studerende. }\end{array}$ \\
\hline Pause 15 min. & & & Løbende votering \\
\hline $\begin{array}{l}\text { Generel diskussion af } \\
\text { projektet: I 1/2 time }\end{array}$ & $\begin{array}{l}\text { De studerende svarer ved at } \\
\text { markere. } \\
\text { Hvis der er nogle der ikke } \\
\text { aktivt rækker hånden op, } \\
\text { bliver der stillet spørgsmål } \\
\text { direkte }\end{array}$ & $\begin{array}{l}\text { Stiller en række spørgsmål vedr. } \\
\text { problemstilling, } \\
\text { valg af metode, } \\
\text { fordele og ulemper ved valg af metode, }\end{array}$ & $\begin{array}{l}\text { Løbende vurdering af de } \\
\text { enkelte studerende }\end{array}$ \\
\hline Pause 15 min. & & $\begin{array}{l}\text { Vurderer om der er nogle af de } \\
\text { studerende, som der skal fokuseres } \\
\text { yderligere på? }\end{array}$ & Løbende votering \\
\hline $\begin{array}{l}\text { Specifikke individuelle } \\
\text { spørgsmål } 1 \frac{1}{2} \text { time }\end{array}$ & $\begin{array}{l}\text { De studerende svarer } \\
\text { individuelt. }\end{array}$ & $\begin{array}{l}\text { Stiller dybere spørgsmål til individuelle } \\
\text { studerende. Enten kommer disse } \\
\text { spørgsmål ind imellem de generelle } \\
\text { spørgsmål eller der er reelt tale om } \\
\text { en fase i eksamen, hvor de studerende } \\
\text { enkeltvis kommer til tavlen. }\end{array}$ & $\begin{array}{l}\text { Løbende vurdering af de } \\
\text { enkelte studerende. }\end{array}$ \\
\hline Votering 15 min. & & & Endelige votering \\
\hline $\begin{array}{l}\text { Mundtlig respons og } \\
\text { karaktergivning } \\
15 \text { min. }\end{array}$ & & $\begin{array}{l}\text { Giver mundtlig respons til det samlede } \\
\text { projekt og begrunder de individuelle } \\
\text { karakterer. }\end{array}$ & \\
\hline
\end{tabular}

Tabel 1. Oversigt over den gruppebaserede eksamensform med individuel bedømmelse.

en række udvalgte ingeniørinstitutioner. Spørgeskemaet er designet i SurveyXact og distribueret via mail til eksaminatorer, censorer og studerende tilknyttet alle tre fakulteter på Aalborg Universitet i 2006 og 2008, mens det i 2007 udelukkende har været sendt til det Ingeniør-, Natur- og Sundhedsvidenskabelige fakultet (INS-fakultet). Spørgeskemaet til de studerende indeholder 29 spørgsmål med over 70 variable, mens der til vejledere og censorer er tale om et lidt mindre omfang. I spørgeskemaet er der en række åbne spørgsmål, som er analyseret med henblik på at kunne tematisere svarene (jf. Kolmos et al., 2008).

De åbne svarkategorier har i høj grad været med til at validere spørgeskemaet. Ved enkelte spørgsmål har flere respondenter stillet spørgsmålstegn ved spørgsmålets betydning eller nærmere tvetydighed, hvorfor spørgsmålet er blevet udeladt ved de gentagne undersøgelser og i databehandlingen. Det er dog vigtigt at understrege, at undersøgelsen udelukkende omhandler respondenternes oplevelser, holdninger og præferencer i forhold til en given situation. Selv om der er spurgt ind til respondenternes handlinger i forbindelse med de to eksamensformer, så vil svarene udtrykke de subjektive fortolkninger og ikke observationer af praksis.

Denne artikel sammenfatter resultaterne fra spørgeskemaundersøgelserne ved INS-fakulteterne, AAU (jf. Kolmos \& Holgaard, 2007a; 2007b; Kolmos et al., 2008). Det særlige ved INS-fakulteterne er, at der her er erfaring med den individuelle karaktergivning siden 2006, hvilket betyder at censorer og eksaminatorer har længere erfaring med den individuelle projekteksamensform end kolleger ved andre fakulteter og universiteter. Det, at der er sammenligningsgrundlag over en større årrække betyder, at respondenterne har høstet de første erfaringer med alternative eksamensformer, hvilket kan indebære en mere reflekteret vurdering. I denne artikel sammenligner vi derfor datasæt fra gruppeeksamen 2006, med individuel eksamen 2007 og 2008.

Tabel 3 viser at svarprocenten i de tre undersøgelsesrunder er mere eller mindre den samme (i et interval fra 31 til $35 \%$ ). Det er på grund af udsendelsesprocedure ikke muligt at få særskilte svarprocenter ud for de tre fakulteter i 2006 og 2008. 


\begin{tabular}{|c|c|c|c|}
\hline $\begin{array}{l}\text { Faser i } \\
\text { eksamensforløbet }\end{array}$ & De studerende & Eksaminator og ekstern censor & Individuel bedømmelse \\
\hline $\begin{array}{l}\text { Individuel eksamen af } \\
\text { studerende I } \\
\text { 25-45 min. }\end{array}$ & $\begin{array}{l}\text { Trækker spørgsmål i projektet } \\
\text { og besvarer }\end{array}$ & $\begin{array}{l}\text { Stiller uddybende spørgsmål til den I. } \\
\text { Studerende }\end{array}$ & Voterer og giver karakter \\
\hline $\begin{array}{l}\text { Individuel eksamen af } \\
\text { studerende } 2 \\
25-45 \text { min. }\end{array}$ & $\begin{array}{l}\text { Trækker spørgsmål i projektet } \\
\text { og besvarer }\end{array}$ & $\begin{array}{l}\text { Stiller uddybende spørgsmål til den } 2 . \\
\text { Studerende }\end{array}$ & Voterer og giver karakter \\
\hline $\begin{array}{l}\text { Individuel eksamen af } \\
\text { studerende } 3 \\
25-45 \text { min. }\end{array}$ & $\begin{array}{l}\text { Trækker spørgsmål i projektet } \\
\text { og besvarer }\end{array}$ & $\begin{array}{l}\text { Stiller uddybende spørgsmål til den } 3 . \\
\text { Studerende }\end{array}$ & Voterer og giver karakter \\
\hline $\begin{array}{l}\text { Individuel eksamen af } \\
\text { studerende } 4 \\
25-45 \text { min. }\end{array}$ & $\begin{array}{l}\text { Trækker spørgsmål i projektet } \\
\text { og besvarer }\end{array}$ & $\begin{array}{l}\text { Stiller uddybende spørgsmål til den } 4 . \\
\text { Studerende }\end{array}$ & Voterer og giver karakter \\
\hline $\begin{array}{l}\text { Individuel eksamen af } \\
\text { studerende } 5 \\
25-45 \text { min. }\end{array}$ & $\begin{array}{l}\text { Trækker spørgsmål i projektet } \\
\text { og besvarer }\end{array}$ & $\begin{array}{l}\text { Stiller uddybende spørgsmål til den } 5 . \\
\text { Studerende }\end{array}$ & Voterer og giver karakter \\
\hline $\begin{array}{l}\text { Individuel eksamen af } \\
\text { studerende } 6 \\
25-45 \text { min. }\end{array}$ & $\begin{array}{l}\text { Trækker spørgsmål i projektet } \\
\text { og besvarer }\end{array}$ & $\begin{array}{l}\text { Stiller uddybende spørgsmål til den } 6 . \\
\text { Studerende }\end{array}$ & Voterer og giver karakter \\
\hline $\begin{array}{l}\text { Mundtlig respons } \\
15 \mathrm{~min} \text {. }\end{array}$ & & $\begin{array}{l}\text { Evt. afrunding samlet hvis de studerende } \\
\text { ønsker dette. }\end{array}$ & \\
\hline
\end{tabular}

Tabel 2. Oversigt over individuel eksamen.

Ved langt de fleste spørgsmål har det været muligt at komme med uddybende kommentarer, hvilket en meget stor del af respondenterne har benyttet sig af. I spørgeskemaundersøgelserne alene foreligger der derfor et ganske omfangsrigt kvalitativt datamateriale. Vi kan dog på ingen måde gengive alle undersøgelsesresultater i denne ene artikel, hvorfor der fokuseres på udvalgte kvantitative sammenligninger, understøttet af et udpluk af citater fra det kvalitative materiale. For en dybere analyse af de kvalitative resultater, se Kolmos et al. (2008).

Baggrundsfaktorerne varierer en smule for de tre undersøgelsesrunder, men med henblik på sammenligning vurderes der dog at være en tilfredsstillende overensstemmelse. Blandt både de studerende, eksaminatorer og censorer var der en overvægt af mænd, og blandt eksaminatorerne var omkring halvdelen uddannet ved AAU. 3 ud af 5 eksaminatorer og censorer havde mere end fem års erfaring eller mere, og disse havde tilsammen praktiseret relativt jævnt over semestrene.

Overordnet kan vi dog konkludere, at der kun er mindre afvigelser i baggrundsfaktorer for respondentgrupperne i 2006, 2007 og 2008.

\section{Faglig forståelse, projektkompetencer og eksamination}

Der er spurgt ind til sammenhæng mellem eksamensformer og faglig forståelse. Resultatet var, at de studerende, der var til gruppebaseret projekteksamen i 2006, i signifikant højere grad oplevede, at deres faglige forståelse blev evalueret til eksamen, og det samme er om end i endnu mere udpræget grad tilfældet for eksaminatorer og censorer, se figur 1.

\begin{tabular}{|l|l|c|c|c|}
\hline År & & Udsendelser & Antal svar & Svarprocent \\
\hline 2006 & $\begin{array}{l}\text { Gruppeeksamen ved alle tre } \\
\text { fakulteter }\end{array}$ & 10.700 & 3.639 & $34 \%$ \\
\hline 2007 & Individuel eksamen ved INS-fakultet & 3.481 & 1.222 & $35 \%$ \\
\hline 2008 & $\begin{array}{l}\text { Individuel eksamen ved alle tre } \\
\text { fakulteter }\end{array}$ & 12.773 & 3.998 & $31 \%$ \\
\hline
\end{tabular}


Figur I. Studerende oplevelse af faglig forståelse. Forskellen mellem studerende 2006 og studerende 2008 er signifikant (Sig = 0,000; Chi-Square $=15,580$ )

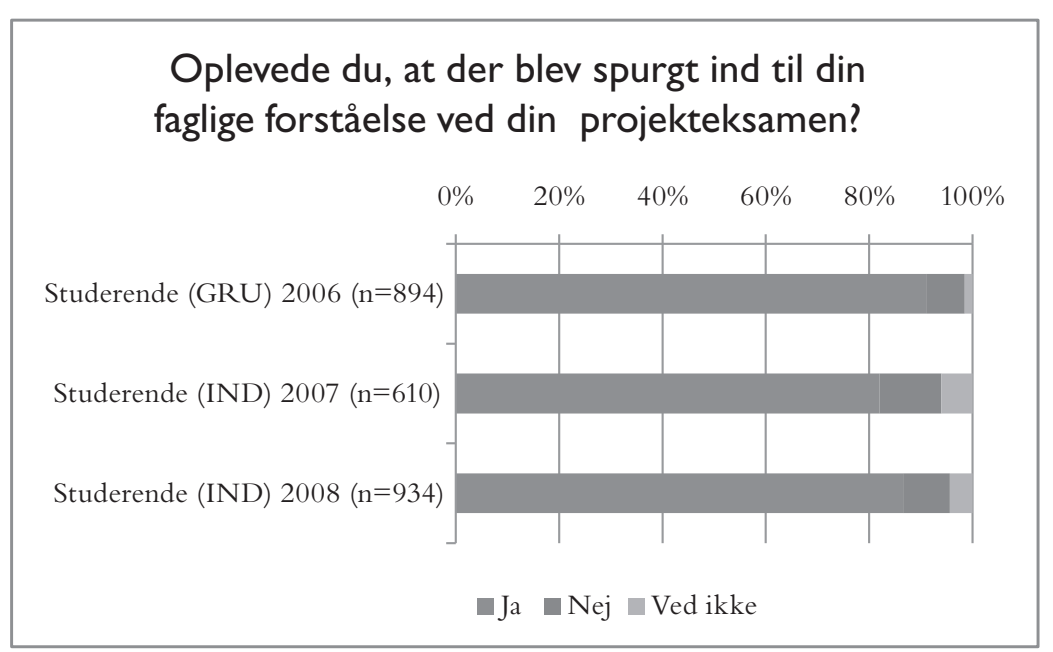

Selvom forskellen er signifikant, er forskellen imellem de studerende, der mener, de er blevet spurgt ind til den faglige forståelse, og de studerende, der mener, de ikke er spurgt ind til denne, dog mindre end 10 procentpoint, og begge eksamensformer må efter de studerendes vurdering siges at teste den faglige forståelse i langt de fleste tilfælde.

Knap halvdelen af eksaminatorer/censorer mener dog, at muligheden for at teste faglig forståelse er blevet ringere eller markant ringere ved den individuelle projekteksamen frem for gruppebaseret projekteksamen, mens kun hver femte ser den individuelle eksamensform som en forbedring. Hvis vi ser på muligheden for at vurdere den enkelte, er der omtrent lige så mange, som mener, at den individuelle eksamensform har været en forbedring, som at den har været en forringelse.

Ser vi på kommentarerne, går argumentationerne for den gruppebaserede eksamen primært på, at gruppeeksamen giver mulighed for en mere dybdegående diskussion, er en lærerig proces og er en naturlig følge på en gruppeproces.Ved en gruppeeksamen er der mulighed for at stille spørgsmål på et fagligt mere og mere avanceret niveau, og hvor ikke alle studerende har evne til at besvare de mest komplicerede spørgsmål.Ved en individuel eksamen er der kun tid til at stille de mere grundlæggende spørgsmål, idet der hele tiden skal startes forfra. De væsentligste kritikpunkter i forhold til den individuelle eksamen er, at denne eksamensform giver for lidt tid til udfoldelse, og tilnærmelsesvist er en eksamen i de til projektet relaterede støttefag. Dette hænger sammen med, at den individuelle eksamen efter flere studerendes mening belønner rutineprægede præstationer med fokus på teori frem for problemstillingen i projektet.

Den individuelle eksamen betegnes også af flere som overfladisk og forbundet med held. Den individuelle eksamen ses dog som en mulig løsning på, at det er svært at komme til orde til en gruppebaseret projekteksamen, at svage studerende ikke kan gemme sig, at man bedre kan blive bedømt individuelt og at karakteren er mere realistisk i forhold til den enkeltes formåen. Andre studerende fremhæver, at det er rart at være til eksamen i så kort tid. En del studerende, der er fortalere for den individuelle eksamen, betinger dog dette med, at projektforløbet afrundes med en fælles fremlæggelse, og at der gives mere tid til den enkelte eksamination.

Ses der i stedet på eksamensformernes rum for at teste forskelligartede kompetencer, er der taget udgangspunkt i tre typer af kompetencer: 1) paratviden, 2) analyse og transfer af viden samt 3) kommunikation og samarbejde. Det samme spørgsmål er stillet til studerendes, eksaminatorers og censorers oplevelse i henholdsvis den gruppebaserede eksamen 2006 og den individuelle eksamen 2007 og 2008. Resultaterne viser, at eksamensformerne er omtrent lige gode til at teste paratviden såsom at svare hurtigt og kunne begreber og definitioner.

Derimod vurderede samtlige respondentgrupper på et signifikant niveau, at den gruppebaserede eksamen er mere effektiv i forhold til analyse og transfer af viden samt kommunikation og samarbejde. Resultaterne fremgår mere specifikt af figur 2,3 og 4 .

Der er således ikke nogen tvivl om, at den gruppebaserede projekteksamen tester mere alsidige kompetencer end den individuelle eksamensform vurderet ud fra samtlige tre respondentgruppers besvarelser. Som en af eksaminatorerne udtrykte det i de åbne kommentarer:

Der er ikke tid til at gå $i$ dybden med noget-hverken overblik, argumenter eller relationer. Det er klar-parat-svar - og kan den studerende ikke det på den angivne tid, så sker der enten det, at vejlederen giver stikord, eller at den studerende må gå med 'uforrettet sag' - og siden hen en dårlig karakter.

Det er en minoritet blandt både studerende, censorer og eksaminatorer, der finder, at den individuelle projekteksamen egner sig til at teste de studerendes analytiske evner, deres evne til at overføre resultater og metoder fra en situation til en anden og deres kompetencer inden for kommunikation og samarbejde. Der 


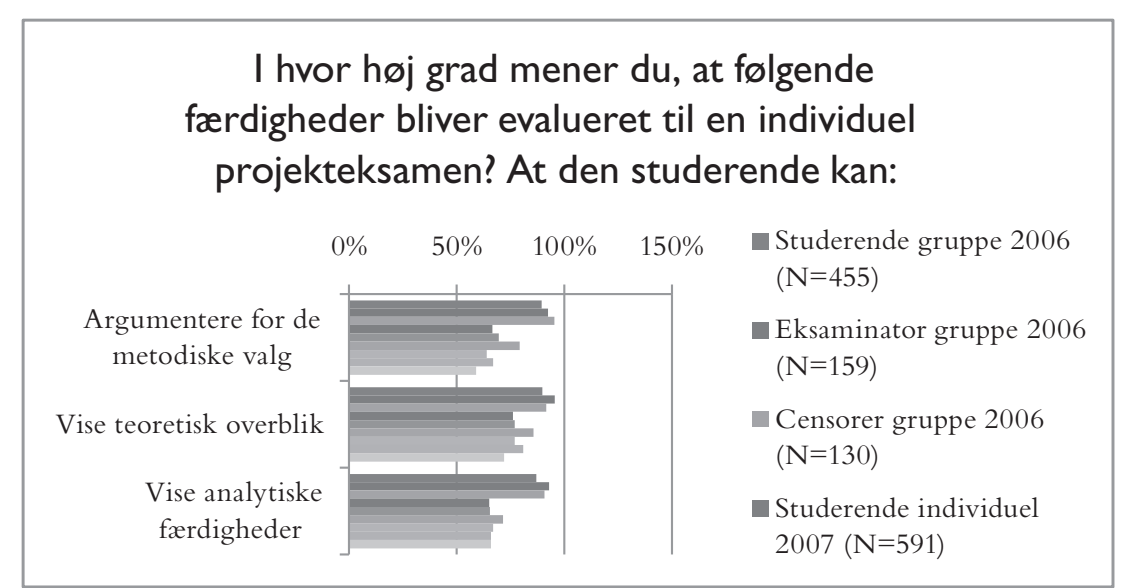

Figur 2. Studerendes, eksaminatorers og censorers opfattelse af, hvorvidt den individuelle og gruppebaserede eksamen i høj eller nogen grad har muliggjort evalueringen af færdigheder.

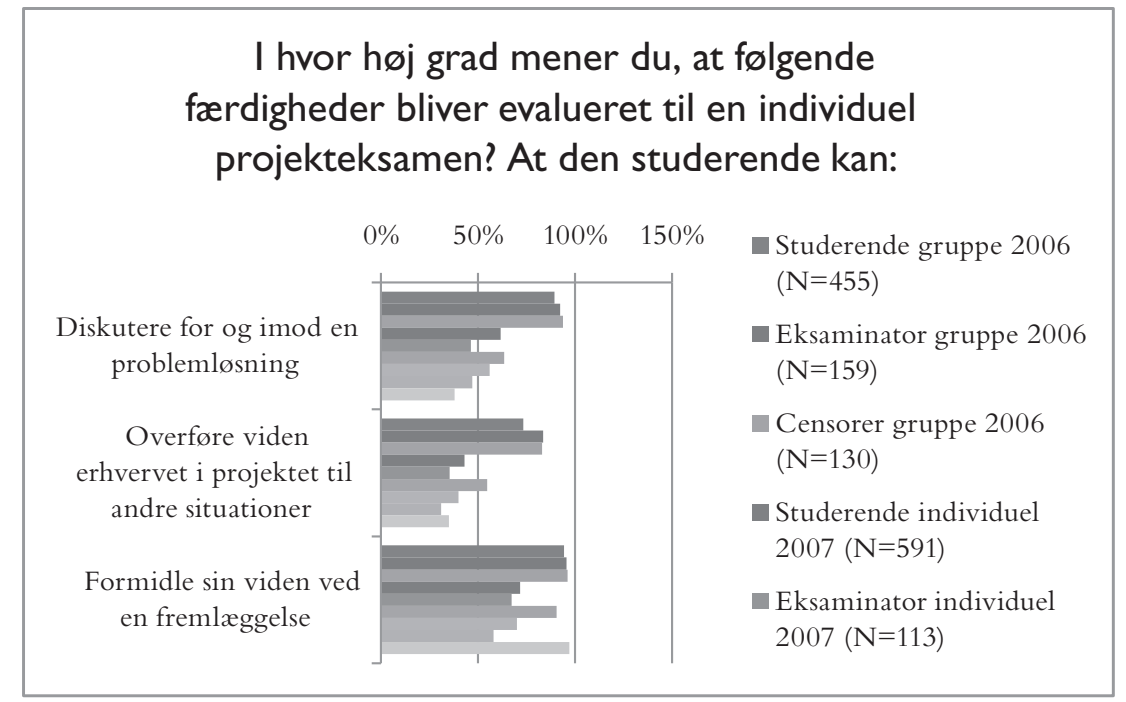

Figur 3. Studerendes, eksaminatorers og censorers opfattelse af, hvorvidt den individuelle og gruppebaserede eksamen i høj eller nogen grad har muliggjort evalueringen af færdigheder.

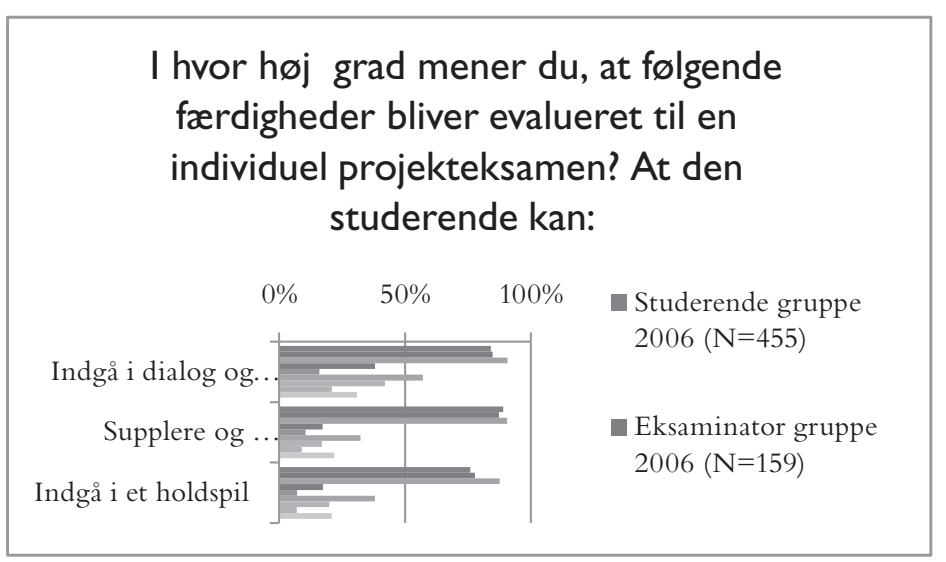

Figur 4. Studerendes, eksaminatorers og censorers opfattelse af, hvorvidt den individuelle og gruppebaserede eksamen i høj eller nogen grad har muliggjort evalueringen af færdigheder. er dermed skabt en disharmoni mellem de faglige mål og eksamensformerne.

En gennemgående kommentar fra de studerende var, at projektarbejdet og projektrapporten er faldet mere i baggrunden, og flere påpegede, at de kurser, der understøtter projektet, i stedet er trådt mere i forgrunden. Som en af de studerende udtrykte det:
"Vores eksamen fokuserede udelukkende på, hvor godt vi var inde i PE-fag. Dvs. at gruppearbejdet og projektet slet ikke blev diskuteret eller kommenteret. Dette bevirkede naturligvis at de medlemmer af gruppen, som havde lurepasset på de andres arbejde med projektet, kunne klare sig flot igennem ved kun at forberede sig på PE-fag. « 
Censorerne og eksaminatorerne viser i de åbne udsagn bekymring omkring den individuelle eksamens manglen på læring, diskussion og dybde. Også eksaminatorerne fremhæver, som de studerende, at projektarbejdet og projektrapporten er faldet mere i baggrunden.

\section{Respons på projektet}

Et af de store kritikpunkter af den individuelle eksamensform er at de studerende ikke længere făr en samlet respons på projektet. Tidligere oplevede de studerende, at de igennem den gruppebaserede projekteksamen fik en samlet respons ved selve eksaminationen. Undersøgelsen viser på dette punkt, at langt flere studerende, der havde været til gruppeeksamen i 2006, mente, at de havde făet en tilfredsstillende respons på deres gruppearbejde, end det var tilfældet i 2007 og 2008, se figur 5.

For de studerende i 2008 viser det sig, at studerende på bachelorniveau i højere grad oplever tilfredsstillende respons, end tilfældet er for studerende på kandidatniveau. Der kan være tale om to forhold, der spiller ind: dels at studerende på bachelorniveau ikke har oplevet gruppeeksamen i samme omfang som studerende på kandidatniveau, men også at der er tale om forskellige typer af projekter, hvor projekter på kandidatniveau mere har karakter af innovations-projekter, hvor de studerende udvikler nye teknologier.

\section{Generel vurdering}

I undersøgelsen er der stillet et generelt vurderende spørgsmål om, hvilke eksamensformer respondentgrupperne ønsker. Som det kan ses af figur 6 , foretrækker knap $50 \%$ af de 907 studerende, der har været til individuel eksamen i 2008, en gruppebaseret eksamen, mens $30 \%$ foretrækker en individuel projekteksamen.

Der er en klar tendens til, at de studerende bliver mere og mere positive over for den individuelle eksamensform, og langt flere studerende, der har været til individuel eksamen mere end 3 gange, argumenterer for en individuel projekteksamen. Der er signifikant sammenhæng mellem erfaring med den individuelle eksamensform og præference (Sig: 0,000; Chi-square: $28,243)$. Der er dog stadig et signifikant ønske om en gruppebaseret eksamensform ved INS fakulteterne.

For eksaminatorer og censorer er billedet mere ensidigt, da omkring 9 ud af 10 foretrækker en gruppebaseret projekteksamen, se figur 7. Det er her bemærkelsesværdigt, at selvom censorer og eksaminatorer har prøvet den individuelle eksamensform flere gange, så bliver de ikke mere positive. Tværtimod er der procentvis færre censorer og eksaminatorer i 2008, der foretrækker individuel eksamen til forskel fra 2007.

Censorernes svar varierer dog meget afhængig af, hvor de er ansat. 2007-undersøgelsen viser, at privatansatte censorer er signifikant mere positive overfor gruppebaseret projekteksamen end offentligt ansatte censorer, se figur 8 . På grund af færre respondenter i censor-gruppen 2008 har det ikke været muligt at foretage signifikansanalyse.

Dette er en ganske interessant forskel, hvor en af forklaringerne bl.a. kan være, at samarbejds- og læringsformerne stemmer bedre overens med arbejdsorganiseringen i det private - som en af censorerne udtrykker det:

"Foretrekker gruppebaseret eksamen med gruppefremlaggelse og gruppe eksamination og diskussion efterfulgt af individuel karaktergivning. Begrundelse - de studerende vil komme ud $i$ en virkelighed, hvor evnen til at indgå $i$ samarbejde med kreativ dialog gor det vigtigt at fokusere på evnen til at udtrykke sig personligt som en del af et samarbejdsteam."

Resultatet for de privatansatte censorer er i tråd med en undersøgelse fra Ingeniørcensorformandskaberne afrapporteret december 2008, som viser, at $70 \%$ af censorerne ser den individuelle eksamen som en forringelse ( $n=1092$, svarprocent 52), og en stor andel af censorerne ønsker derfor forbuddet mod den gruppebaserede eksamen ophævet (Ingeniørcensorformandskaberne 2008).
Figur 5. Studerendes oplevelser af respons i en gruppeeksamen og individuel eksamen. Studerendes individuel 2007/gruppe 2006 og oplevelse af respons ved projekteksamen: Signifikant og stærk sammenhæng (Sig = 0,000; Gamma = 0,623).

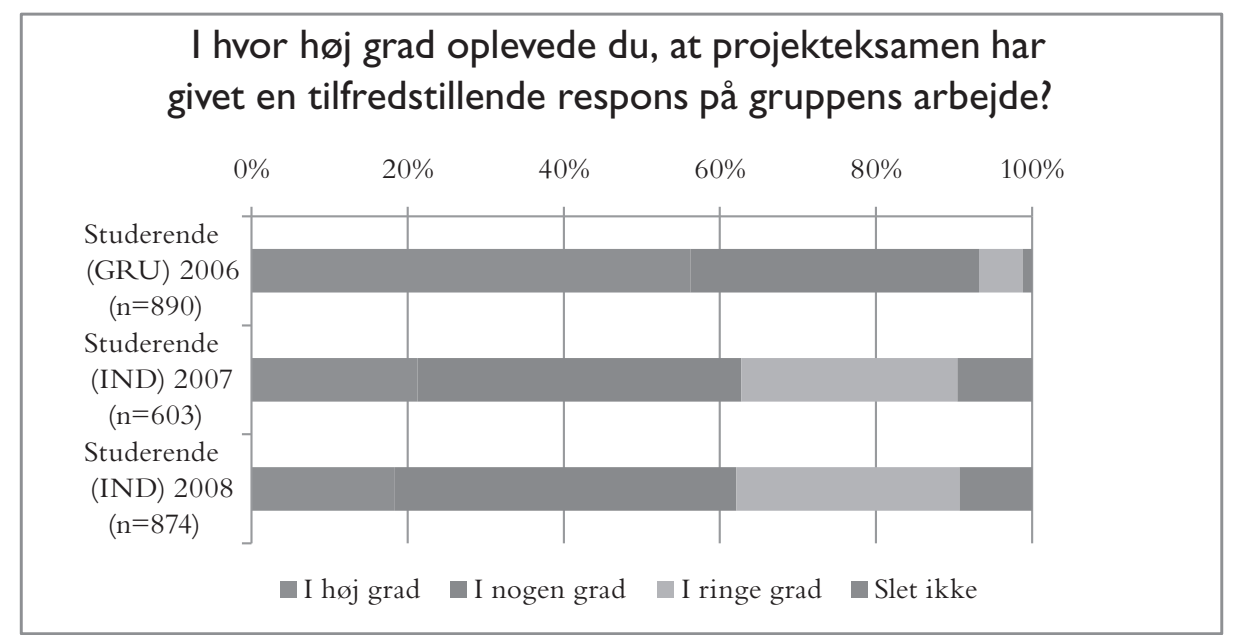




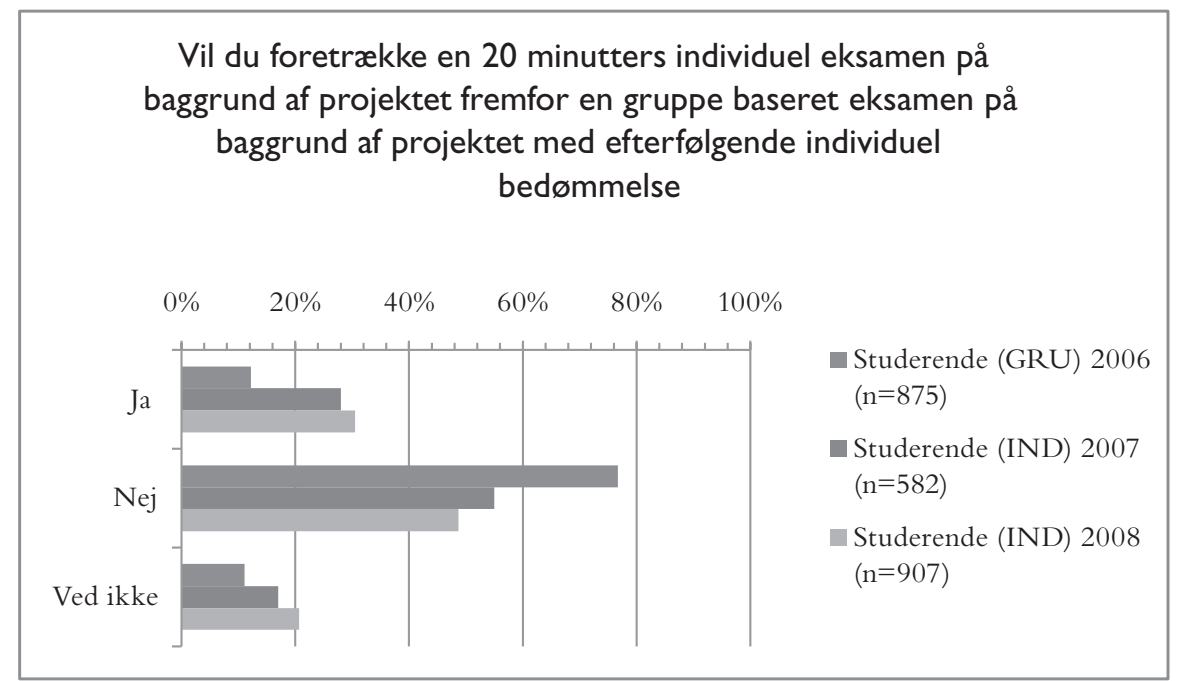

Figur 6. Sammenligning mellem de studerendes præferencer 2006, 2007 og 2008. Der er signifikant forskel mellem grupperne. Sig: 0,000; Chi-square: 150,907

Vil du foretrække en 20 minutters individuel eksamen på baggrund af projektet fremfor en gruppe baseret eksamen på baggrund af projektet med efterfølgende individuel bedømmelse

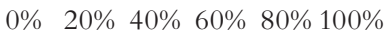

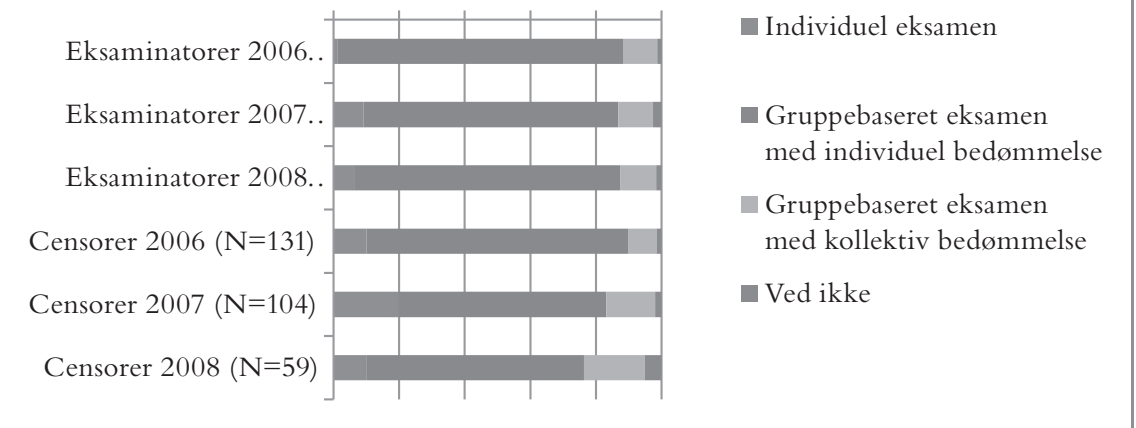

Figur 7. Eksaminatorers og censorers prioritering af eksamensformer, 2006 , 2007, 2008

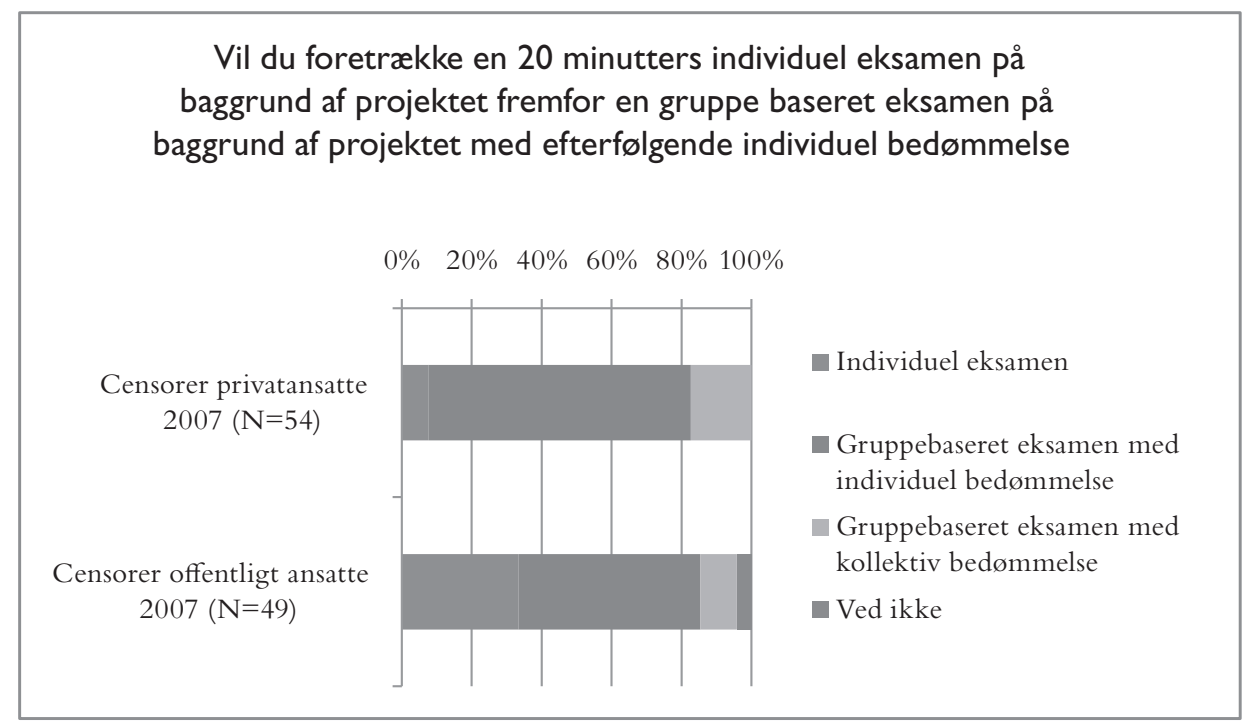

Figur 8. Privatansatte og offentlig ansattes prioritering af eksamensformer. Censorer privat/offentlige og preference i forhold til eksamensform: Signifikant ved 0,026 niveau.

\section{Konklusion og perspektivering}

I denne artikel har vi behandlet styrkerne og svaghederne ved henholdsvis den gruppebaserede og individuelle projekteksamensform i forhold til at teste faglig forståelse og den brede vifte af kompetencer, der forventes efter et problemorienteret projektarbejde; samt at give de studerende respons på deres projektarbejde gennem både kontrol og perspektiverende spørgsmål. 
Resultaterne viser en klar tendens til, at den individuelle eksamensform ikke rummer den samme mulighed for at teste en række centrale projektkompetencer, og den respons, de studerende făr til deres projekt ved denne eksamensform, bedømmes som mindre tilfredsstillende. De problemer, som undersøgelsen rejser omkring anvendelse af den individuelle eksamensform, er bl.a. at der ikke længere er mulighed for at give en samlet respons på projektet, og at eksamen bliver til kontrol af basal viden i stedet for en test af de studerendes analytiske, metodiske og kommunikative evner i løsning af teknologiske problemstillinger. Især eksaminatorer finder, at det er vanskeligere at komme i dybden med den faglige viden inden for de givne tidsrammer.

Ud fra et didaktisk synspunkt synes der derfor ikke at være tilstrækkelig overensstemmelse imellem uddannelsens mål, indhold og evalueringsformer, når den individuelle eksamination viser sådanne svagheder inden for en række centrale projektkompetencer. På dette grundlag kan det diskuteres, om den individuelle eksamen er en gyldig metode til eksamination af et problem- og teambaseret projektarbejde. Det nærmer sig det paradoksale at sige ja til et teambaseret projektarbejde, men nej til teambaseret eksamination. Det svarer til at teste bandmedlemmers kunnen ved solooptræden.

Majoriteten af de studerende, eksaminatorer og censorer, som besvarede spørgeskemaet, foretrækker en gruppebaseret projekteksamen med individuel bedømmelse. De privatansatte censorer er de stærkeste fortalere for en gruppebaseret eksamen blandt de censorer, der besvarede undersøgelsen, og de argumenterer især for at projektarbejde med tilhørende gruppebaseret eksamensform svarer til arbejdsformer i erhvervslivet.

De studerende er dog blevet noget mere positive overfor den individuelle eksamensform i 2008 end de var i 2006. Dette kan have flere årsager. Nogle studerende har måske følt sig utrygge ved den individuelle eksamensform, der i 2006 var ukendt i forbindelse med projekteksamen. En anden forklaring kan omvendt være, at der er en stor del af respondenterne i 2008, der aldrig har prøvet den gruppebaserede eksamensform, hvorfor denne eksamensform nu kan danne grobund for usikkerhed. En anden forklaring kan være et skift i holdningen til, hvad der bør testes.

Det må også tages i betragtning, at studerendes forventninger, og eksaminator og censors læringssyn og kompetencer som eksaminatorer, kan have indflydelse på, hvordan eksaminationen opfattes. Ses der på nærværende undersøgelse, synes den individuelle eksamensform hverken effektiv eller ønsket. Der er således ikke mange argumenter at hente i denne undersøgelse til at understøtte regeringens beslutning om afskaffelse af gruppeeksamen, ej heller i undersøgelser fra andre fakulteter og ingeniørinstitutioner (jf. Holgaard et al., 2008a; 2008b; Clemmesen et al., 2008). Det er derfor meget svært forståeligt, at der ikke tages hensyn til forskningsresultater, ønsker fra DI, Dansk Erhverv, FRI, Ingeniørcensorformandskaberne og en lang række virksomheder, som har udtalt sig imod forbuddet.

Det rejser også spørgsmål om den videre skæbne for problem- og projektbaseret læring i DK? Vi kan håbe på flere nuancer i debatten og mere variation $\mathrm{i}$ lærings- og eksamensformer. Der kan være fordele ved den individuelle eksamensform, idet der ligger en "sikring" af, at alle studerende har tillært sig den fornødne basisviden inden for et felt. På den måde ville denne eksamensform spille fint overens med mere snævre disciplin-projekter, hvor projektgruppen mere fungerer som en studiegruppe.

Men for innovations-projekter, hvor de studerende udvikler ny viden - ofte af kompleks karakter - fungerer den individuelle eksamensform ikke. I innovationsprojekter er der oftest tale om, at de studerende arbejder som individuelle eksperter i teams. I sådanne projekter kan det være uholdbart, at hver enkelt studerende i ligeligt omfang skal kunne stå til ansvar for hele projektets pensum, og det er et spørgsmål om, hvor lang tid uddannelsesinstitutionerne kan motivere de studerende til at gå i gang med disse langt mere risikobetonede og komplekse innovations-projekter, hvis ikke eksamensformen understøtter synergien i teambaseret læring. Det bekymrende er, at det jo netop er innovations-projekterne, som giver et tættere samarbejde mellem uddannelse og erhvervsliv. Så på sigt vil der være risiko for, at der opstår større afstand til det omgivende samfund i og med, at universiteterne tvinges i en mere skolastisk retning.

\section{Referencer}

Biggs, J. (2003). Teaching for Quality Learning at University. The Society for Research into Higher Education and Open University Press.

Clemmesen, S.H., Holgaard, J.E., \& Kolmos, A. (2008). Projekt GruppeEksamen: delrapport 6: Individuel og gruppebaseret projekteksamen ved Det Samfundsvidenskabelige Fakultet, Aalborg Universitet. En sammenligning imellem gruppebaserede projekteksaminer 2006 og individuelle projekteksaminer 2008. Dansk Center for Ingeniøruddannelse.

Dochy, F., Segers, M., \& Sluijsmans, D. (1999). The Use of Self-, Peer and Co-asessment in Higher Education - a Review. Studies in Higher Education, 24(3).

Gibbs, G. (1999). Using Assessment strategically to Change the Way Students Learn. I: S. Brown, \& A. Glasner (eds.). Assessment Matters in Higher Education (pp. 41-54). The Society for Research into Higher Education and Open University Press

Graaff, E. de (2004). The impact of Assessment on the ProblemBased Learning Process. I: M. Savin-Baden, \& W. Kay (eds.). Challenging Research in Problem-Based Learning. Society for Research into Higher Education and Open University Press.

Graaff, E. de, \& Kolmos, A. (2007). Management of Change Implementation of Problem-Based and Project-Based Learning in Engineering. Netherlands: Sense Publishers.

Heathfield, M. (1999). Group-based Assessment An evaluation of the use of Assessed Tasks as a Method of Fostering Higher Quality Learning. I: S. Brown, \& A. Glasner (eds.). Assessment Matters 
in Higher Education (pp. 132-145). The Society for Research into Higher Education and Open University Press.

Hiim, H., \& Hippe, E. (1997). Laring gennem oplevelse, forståelse og handling - en studiebog i didaktik. København: Gyldendal Undervisning.

Holgaard, J.E., Kolmos A., \& Clemmesen, S.H. (2008a). Projekt GruppeEksamen: delrapport 3: Projekteksaminer ved Ingeniørhøjskolen Odense Teknikum, Ingeniørhøjskolen i København og Vitus Bering. Dansk Center for Ingeniøruddannelse.

Holgaard, J.E, Clemmesen, S.H., \& Kolmos, A. (2008b). ProjektGruppeEksamen: delrapport 4: Individuel og gruppebaseret projekteksamen ved Humanistisk Fakultet, Aalborg Universitet. En sammenligning imellem gruppebaserede projekteksaminer 2006 og individuelle projekteksaminer 2008. Dansk Center for Ingeniøruddannelse.

Ingeniørcensorformandskaberne (2008). Evaluering af eksamen baseret på baggrund af et gruppefremstillet produkt, Undersegelse foretaget blandt samtlige beskikkede censorer indenfor ingeniørkorpsene. Ingeniørcensorformandskaberne, www.censornet.dk, December 2008

Joughin, G. (1999). Dimensions of Oral Assessment and Students' Approaches to Learning. I: S. Brown, \& A. Glasner (eds.). Assessment Matters in Higher Education (pp. 146-156). The Society for Research into Higher Education and Open University Press.

Knight, P.T., \& Yorke, M. (2003). Assessment, Learning and Employability, The Society for Research into Higher Education and Open University Press
Kolmos, A., \& Holgaard, J.E (2007a). Delrapport 1: Sammenligning af gruppebaseret og individuel eksamen sommer 2006 ved Fakultet for Ingeniør-, Natur- og Sundhedsvidenskab. Dansk Center for Ingeniøruddannelse.

Kolmos, A., \& Holgaard, J.E. (2007b). Delrapport 2: Individuel og gruppebaseret projekteksamen sommer 2006 og 2007 ved Fakultet for Ingeniør-, Natur- og Sundhedsvidenskab. Dansk Center for Ingeniøruddannelse.

Kolmos, A, Holgaard, J.E., \& Clemmesen, S.H. (2008). Projekt GruppeEksamen: delrapport 5: Individuel og gruppebaseret projekteksamen ved de Ingeniør- Natur-og Sundhedsvidenskabelige fakulteter (INS), Aalborg Universitet. En sammenligning imellem gruppebaserede projekteksaminer 2006 og individuelle projekteksaminer 2008. Dansk Center for Ingeniøruddannelse.

Lejk, M., Wyvill, M., \& Farrow, S. (1997). Group learning and Group Assessment on Undergraduate Computing Courses in Higher Education in the UK: results of a survey. Assessment and Evaluation in Higher Education, 22(1).

Sawyer, K. (2006). Explaining Creativity. Oxford University Press

Sawyer, K. (2007). Group Genius - The Creative Power of Collaboration. New York: Basic Books.

Webb, N.M. (1993). Collaborative Group Versus Individual Assessment in Mathematics: Processes and Outcomes. Educational Assessment, 1(2), 131-152. 